\title{
Characteristics and Role of Women at Small Industries Manufacturing Leading in Sumedang- Indonesia and gender inequality are felt
}

\author{
${ }^{*}$ Umi Zuraida1 ${ }^{1}$ Ahmad Trias², Sri Herliana ${ }^{3}$, Sri Hartati ${ }^{4}$ \\ 1,3,4 School of Business and Management Institute Technology Bandung (ITB), Indonesia \\ 2 Engineering Department of Winaya Mukti University \\ *umi.zuraida@sbm-itb.ac.id
}

\begin{abstract}
The purpose of this study is to know the characteristics, role and gender inequality that was received in a workplace and in the home by women who work at small industries manufacturing leading in Sumedang district. Result of study can be used as a reference in realizing the government's policy of increasing role of women's doubles at the small industries. The research use descriptive analysis. Sample is 60 women who work at 15 main small industries that were taken by purposive. Primary data with questionnaire accompanied by interviews and direct observation. Women who engaged in small industries in manufacturing commodity Sumedang district have characteristic: all within the productive age with the highest number (76\%) between 16 -30 years. Majority (60\%) from primary school and $90 \%$ earn below the minimum wages. $50 \%$ of respondents turn over all the proceeds to the family, because motivation of their work is 53\% to help their husbands in order to improve economy of family. Contribution to the family economy is $60 \%$ contribute very small, because their contribution just becomes part of the contribution of all other family members. Their role is majority (60\%) at finishing and packing. The respondent feel there is gender equality at the workplace, but there is still inequality in the family even though they not feel that it is an inequality.
\end{abstract}

Keywords: Characteristic, Role of Women, Small Industries, Industries Manufacturing leading, gender inequality

\section{Introduction}

Problem back ground: In Sumedang-Indonesia, The economy drove by Small scale Industries which contributed 58.47 percent, including the Small Industries that were producing main Commodity who has accounted for 80 percent of the contribution of the regional economy. Small industry and handicrafts which mostly is a business legacy of more than $70 \%$ of workers in this industry are unpaid workers, including women workers. This indicates that most of these businesses are family businesses and there are assisted by family members as employees (BPS, 2003). The division of labor between men and women often causes gender bias where men are culturally and structurally not obligated to work domestic area because it is the responsibility of women. But when a woman entered the productive workforce area, it is considered legitimate and reasonable even implicitly implied an obligation to help economic of family and must fixed perform domestic work. This suggests that the dual role of women has been accepted by the society, but the dual role of men have not. This study conducted to realize the government's policies in order to improve the dual role of women, especially in small industry that has shown her strength in the face of economic recession, especially in districts Sumedang. Gender bias resulted in a woman who works productively yet all recognized as workers. Moreover, women who do work in the home (home industry), he cannot separate himself to the role of gender in the domestic sector. Gender bias also resulted in the participation of women is at such a low position as a workers, employees, family workers or as unpaid family workers dependent on the husband. This inequality must be looked and anticipated by the government, so the female workers who participated in regional and national development are no longer in a marginal position, did not understand his rights, not independent and treated less human.

Research objective: The purpose of this study was to know the characteristics, role and gender's inequalities that were received in a workplace and in the home by women who work at small industries manufacturing leading in Sumedang district of Indonesia. 
The Importance of Research: Result of study can be used as a reference in realizing the government's policy to increasing role of women's doubles in national development economic especially at the small industries in Sumedang district.

\section{Literature Review}

SMEs are an important part of a development of nation's economic and social structure, it is a worldwide fact (Shaikh et al., 2011). While Ram et al., 2011), told that in global perspective SMEs have acquired a significant importance in the economic growth and development of a country and the women have a lot of opportunities to actively participate in the economic activities. According to Alex and Naomi (2004), Small industry manufacturing is a small industry that has stages of processing, both in advanced mechanization and mechanization of traditional. In this industry, it usually can be separated into activities related to production, marketing and activities of administration / general. Related with economic development and poverty reduction, the role of women as an entrepreneur are vital towards the economy of nation (Ekpe, 2011). But many issues which are facing women to participate in economic activities at the national and international level (Faridi et al., 2009). One of issues is the lack of education and economic opportunities for women restrict the potential to think about their due rights (Babur, 2007). Whereas the education of woman can improve their socio-economic status and they may contribute in society more fruitfully (Khalique, Isa, Abu, Shaari, Jamal \& Baba (2011).

In Pakistan women are facing various forms of violence, such as discrimination and inequality in almost every aspect of life and taking breathe in strict family, religious, and tribal customs (Abrar and Ghouri, 2011). While In Mexico, at manufacturing firms especially in foreign-owned export firms, there are discriminated in the wage gap. Women receive less in terms of wages (Villarreal and Wei-hsin, 2007). While in India, formal job opportunities for women at the national and state levels are effectively very limited and they are highly concentrated in a small number of manufacturing industries, such as tobacco, apparel, food, weaving (Chattopadhyay, Chakraborty and Anker, 2013). Collins (1991) stated that the differences between women and men who have been socialized in the family, then reflected in the tendency for women's job to take orders, and give orders to the men's work. This has an impact on the treatment of women both in the domestic and public areas. The role is a set of norms that restrict how a person is expected to bring a certain behavior in a social position (Bolzendahl, Myers, 2004). Meanwhile Robbins (2001), states that the role is a set pattern of behavior expected of someone occupying a given position in a social unit.

Establishment of the role differences between women and men, in which women's power in the the home and men outside the house can be seen from the perspective Berger and Luckmann (1976):

1. The Social construction, which explains how the process of beginning the domestic fields and public areas were formed, namely because:

a. The process of externalization, which is a value hat, is produced by an individual of that does not exist.

b. The process of objectification, i.e. agreements had become a social reality or the process of rejection and acceptance process so that reality is formed.

c. The process of internalization, i.e. from individuals themselves because the individual is actually a part of the social community.

2. Reproduction Social, which is how the actual difference in domestic and public areas were strengthened / intensified, this is done:

a. With symbols, such as the establishment of ' Dharma Wanita ' which actually strengthen the position of women in the domestic field and men in the public sphere .

b. Reproduction biological status of women, for example women are weak creatures, related to women 's health, childbirth, women who are menstruating so that emotional can disadvantage women in the workplace .

c. Reproduction cultural status of women, for example, women are more painstaking, neat, etc., so that women are given jobs that do not require high skills (as marginal workers).

Another thing that also can create barriers for women are stereotyped gender roles. According to Judd \& Park (1993), the stereotype is a collection of individual beliefs about the characteristics or properties of the group. 
Gender's role stereotypes are beliefs that distinguish between the role of the nature and capabilities of women and men in different roles. Consider the gender stereotypes of women as more expressive, more independent less emotional, less logical, less oriented and more participatory than in men for example... In contrast, men are more often perceived as less warm and less sensitive interpersonal, less expressive, more autocratic and focused than in women. These stereotypes are consistently causing men to become better leaders than women. Although it is not always negative, but stereotypes can lead to wrong decisions. This stereotype is also very detrimental to women because women were not getting the same opportunities as men and discrimination against women workers are becoming increasingly widespread.

In Indonesia, basically there are three basic principles related to women, namely: the principle of integration of women in development; the principle of equal partnership between men and women both in the family, in society, and in implementing national development; and the principle of the dual role of women, in terms of balance, harmony, and harmony between its role in the family and his role as agents of development (Ambaretnani, 1994). Policies of Indonesian government in order to increase a woman's role is: Improving the quality of women as resource development; the role of quality improvement and protection of labor; improving the quality of the dual role of women as equal partners of men in the family and society; development of social and cultural climate that supports the advancement of women; and strengthening institutional development to increase the role of women and women's organizations. In this study, the role of women in the small manufacturing industry meant in any position of women showed a pattern of behavior that is expected by each of the positions in the activities of small manufacturing industries. Because Small Industrial Manufacturing Company is possible to be on the structure of the upstream industry, the industry, and downstream, the role of women in this industry will be seen starting activities in the provision of raw materials / products initial process, the transformation of raw baha / early products, finished products and the management of post-production , marketing and environmental adaptation both to financial institutions, governments, competitors, and market / consumer / community as well as general and administrative activities. In addition, because of the small industrial enterprises manufacturing in addition to the owners and workers of the managerial side is composed of the top leadership (top management), chairman of the medium (middle management) and leadership (lower management), the role of women in the industry will also be seen from all The level.

\section{Methodology}

In this research, use descriptive analysis with 60 women who work at 15 small industries manufacturing leading in Sumedang district as samples. The samples were taken by purposive random sampling so more describe the fact. Meanwhile, primary data collection is done using a questionnaire accompanied by an interview. For secondary data collected by checklist and institutional. The population in this study are women involved in small industrial commodities air rifle, tofu, wood processing, kite yarn and furniture. Determination of the population at these commodities are based on the consideration that the Small Industries selected are small industries that majority and Sub-districts Jatinangor and Cimanggung is Subdistrict that contributes the largest industrial sector (accounts for more than 40 percent) for the GDP of Sumedang district. To determine the contribution of women in the household income of small industries will be analyzed and interpreted descriptively based on the amount remitant (the amount of income that is donated) in percentage of the value of total household income by the formula.

$$
\mathrm{C}=(\mathrm{I} / \mathrm{TI}) \times 100 \%
$$

where: $\quad \mathbf{C}=$ Contribution to the total household income

$$
\mathrm{I}=\text { Income that contributed to the household income }
$$

$\mathbf{T I}=$ The total household income.

The value of $\mathrm{C}$ ranges from 0 to $100 \%$. The larger $\mathrm{C}$ means the greater the contribution of women engaged in small industries in the economy of the family, but despite great contribution does not mean they have a strong Position in the family. To characterize the level of significance of the contribution of women engaged in small industries in the economy of the family used five criteria as follows: 
Table 1: Categorization Significance of The Contribution Of Women Engaged In Small Industries In The Economy of The Family

\begin{tabular}{lll}
\hline Limit Value of significance Contributions (\%) & Category of Contribution (C) & \\
\hline $0 \leq$ value $<20$ & very small & $\mathbf{1}$ \\
$20 \leq$ value $<40$ & Small & $\mathbf{2}$ \\
$40 \leq$ value $<60$ & Medium & $\mathbf{3 .}$ \\
$60 \leq$ value $<80$ & Quite large & $\mathbf{4 .}$ \\
$80 \leq$ value $<100$ & Very large & $\mathbf{5 .}$
\end{tabular}

\section{Results and Discussion}

Small industrial manufacturing workforce studied is the industry conducts business from generation to generation and has been producing between 5-15 years. Generally the employees are his own family and neighbors some industry makes production sites as well as a marketing venue, such as an air rifle industry, wood processing and furniture. Whereas for tofu industry and kite yarn, besides marketed at production site also distributed to other places.

\section{Characteristics of Women at Small Industries Manufacturing Leading in Sumedang}

Age and Status: According to simanjuntak (1995), level of age will effect on a person's physical ability to work. level of labor force participation will increase in accordance with increasing age and will begin to decline back towards old age. A person is classified in the productive age when aged between 15 years to 64 years. Being unproductive age when a person's age is less than 15 years old or over 64 years (BPS, 2005). Referring to this provision, then the women who work in small industry leading commodities in Sumedang district are all located in the productive age, with minimum age is 16 years old and the oldest 50 years old and $76 \%$ of those between $16-30$ years old. Meanwhile their status is $23 \%$ were unmarried, $60 \%$ were married and $17 \%$ widowed. Of those who are married or widowed, only $60 \%$ who already have children. $45 \%$ have one child, $28 \%$ have two children, $17 \%$ have three children and $10 \%$ have four children. From these data it can be concluded that women who work in small industry leading commodities in the district Sumedang majority are young mothers who are in the productive age.

Education: Education of women workers in the object of the research is: up to primary level as much as $60 \%$, to the junior level there is $30 \%$, and only $10 \%$ to the high school level. This situation is almost same as in Pakistan where one reliable survey in 2000 reported that female participation rates in schools are $45 \%$ at the primary level, $32 \%$ at the middle level and $27 \%$ at the secondary level (Khalique, , Shaari, Jamal, Baba ,2011). This fact indicates that the statement of Suksesi (1991) which states that culture is rooted in the most rural communities (especially in Indonesia) which assumes that a girl had to succumb and do not continue their education in higher also apply to the study respondents. In addition, it also shows that the types of jobs available to women workers in small industries the leading commodities at the district Sumedang do not require Formal high intelligence.

Wages: Wages of women who work in small industrial leading commodities at this Sumedang district, a majority $(90 \%)$ is still below of regional minimum wages. This condition may be related with education and characteristic of their job. Female jobs often do not require skill and physical strength. although under from the regional minimum wage, but $50 \%$ of respondents stated that all income from their small industries provide to help their family, $46.7 \%$ giving partial his income to their family and only $3.3 \%$ is used alone. According to Babur (2007) that the lack of education and economic opportunities for women restrict the potential to think about their due rights. Related about wages, be found too that foreign-owned export firms discriminate against women less in terms of wages In Mexico (Villarreal \& Wei-hsin, 2007). Hence, local governments have to concern to women who work at area of productive and make regulation about salary of female employee so women get equal reward with men.

Motivation: Motivation of women who work in small industries are: a. to improve the economy of the family / help husbands (53\%), b. to meet the needs of the child as already widowed (17\%), c. to help parents (20\%), 
d. to earn their own income (10\%). This means the women who work in small industry already has the awareness to be an independent woman who plays a double at area of domestic as well as in public areas. They are ready to bear the risk for their dual role by running out of time and energy. They ready to be independent, and not dependent on husbands or parents. This independence will make them have greater bargaining power and can decrease assumption that woman not independent, especially in terms of the economy. This development will increase the confidence of these women so that they can increase their courage to get the same rights as family members are male.

Contribution to The Household Income: The Result of this study also shown that contribution of the women who Involved in Small Industries against his family income is: 60\% contribute very small, 13\% contribute small , 23\% contribute quite large and 4\% contribute very large. Based on observations and interviews in the homes of respondents, there are many respondents from poor family economic conditions. This evident from the condition of the house is very simple that inhabited by several families (this condition often encountered at Indonesian rural homes). In these homes, children who are married and already have children still gathered in one house (big family). Hence, in the house there are three to four generations consisting of father, mother, children, grandchildren and children from grandchildren. All of them, who live in that house, contribute to the family economic. Therefore, it is natural that the contribution of the women involved in small industries, majority small percentage because it just becomes part of the contribution of all other family members. Although a small contribution, but with the contribution of these women, especially those who give all their income from small industries to his family, showing how attention of women in the family economy. The sacrifice of these women is not a small sacrifice, because on average they work for 10 hours with 1 hour break every day and they work for six days in a week.

Despite women who work in small industries very busy, but that is not eliminate their domestic duties, chiefly those who are already married or widowed. Nevertheless, a dual role which they do with a full consciousness does not get deserved recognition of his family. This is supported by the results of studies in which $70 \%$ of respondents stated that his family considers a dual role that they do is normal, even $30 \%$ stated that his family considers that they have to work in public areas to help the family economy without abandoning their domestic duties. These condition as in Pakistan (Khalique, Isa, Shaari, Jamal, Baba), that uneducated and unskilled women are mostly serving as an unpaid family helpers and their role in society and even in family is very less appreciated. Therefore, needs to be increased awareness of the husbands and other male family members that women who work at small industries doing noble work to improve the economy / helps husband and this is sacrifice. Therefore, it is expected that the husband and other male family of the female workers engaged in small industries at Sumedang willing to assist the domestic work of these women. With this assistance, the power of women working in small industries at the city Sumedang can be saved so that it can increase productivity at small industries. This increased productivity is expected to increase income and will definitely improve the welfare of the family and will also increase gross domestic product of Sumedang district.

Role of Women at Small Industries Manufacturing Leading in Sumedang: In a small industry, often found that owner doubles as a leader of the upper level, lower secondary and even as workers executor. It also occurs in small industries in Sumedang district where $10 \%$ of women engaged in small industries which became the object of study is the owner of the company, while the remaining $90 \%$ are worker. However, although as the owner, but they also do operational working related to customer service, including as a cashier. Even in the kites yarn industry, they participate directly involved in the activities of finishing (final settlement and packing). For workers, $23 \%$ handle general administration, $60 \%$ at finishing and packing, and $17 \%$ of respondents in the customer service position. These facts occur because of majority of small industrial work is still done manually so for production jobs that require high-risk labor force, still rely on male employees. It described that stereotype that women are weak and need to be protected is still attached in this small industry.

Inequalities in the Workplace: In Small Industries Manufacturing Leading in Sumedang district there is a difference in wages between male and female employees. However, this difference is more due to differences in the type of work where the types of work men generally need more physical strength and have a greater risk than type's job of female employees. So that the women involved in small industries in manufacturing 
commodity Sumedang district assume that the wage difference is a reasonable, not inequality. This result as same as the result of Villarreal and Wei-hsin (2007). They found that In Mexico, foreign-owned export firms discriminate against women in terms of wages, in which Women employees get wages less than men employees. In addition, in this small industry, $100 \%$ of respondents feel they have received the same treatment with the male employees as well as all the respondents also felt his presence was considered by the employer and male employees in the industry became an important part in the company and they feel appreciated. In addition, the majority of respondents felt get permission easily when they have to finish their health problems or other problems

Inequality in the Family: The results showed that husband of the woman who become respondents in this study less awareness to help resolve domestic work, because $26.7 \%$ husband never helped his wife for resolve domestic work, only $13.3 \%$ are often helped finish the housework, and $60 \%$ sometimes helps. Similarly to son or a male family member to another. $13.3 \%$ respondents stated they never assisted, 46.7 respondents who stated they occasionally assisted, $27 \%$ respondents who stated they somewhat frequently aided and only $13 \%$ respondents stated that they were assisted each day. These results indicate that there is still inequality in treatment between men and women in the family, but the respondents do not consider it as an inequality. It is related with a culture rooted in rural communities who assume that girls should receive lower wages when working, had to work hard while carrying the child in the domestic sector and should not continue to a higher school (Suksesi, 1991). In addition, these results are in accordance with the stereotypes that when women perform multiple roles in the domestic and public areas, it's considered reasonable because she should help the economy of the family, while the men's double role to help resolve household work has not been fully accepted.

\section{Conclusion}

Women who work in small industry leading commodities in the district Sumedang have characteristic: They typically work for 9 hours per day. Majority are young mothers who are in the productive age, with the youngest age is 16 years old and the oldest 50 years. The highest number $(76 \%)$ aged between 16 -30 years. A total of $23 \%$ unmarried, $60 \%$ married, $17 \%$ widowed. Of those who are married or widowed, only $60 \%$ who already have children. $45 \%$ have one child, $28 \%$ have two children, $17 \%$ have three children and $10 \%$ have four children. Their education is up to primary level as much as $60 \%$, to the junior level there is $30 \%$, and only $10 \%$ to the high school level. Majority (90\%) earn below the minimum wages but $50 \%$ of respondents turn over all the proceeds to the family, $46.7 \%$ gave partial and only $3.3 \%$ who used his own income. Motivation of women who work in small industries are: a. to improve the economy of the family / help husbands (53\%), b. to meet the needs of the child as already widowed (17\%), c. to help parents (20\%), $d$. to earn their own income (10\%). Contribution of the women who Involved in Small Industries against his family income is: $60 \%$ contribute very small, $13 \%$ contribute small, $23 \%$ contribute quite large and $4 \%$ contribute very large. This is because there are several family in their house, so contribution of respondent to family economy just becomes part of the contribution of all other family members

The role of women in small-scale industries in the district of manufacturing commodities Seeding are $10 \%$ as the owner of the company and $90 \%$ are implementing worker. However, although as the owner, but they also do operational working related to customer service, including as a cashier. Even in the kites yarn industry, they participate directly involved in the activities of finishing (final settlement and packing). For workers, $23 \%$ handle general administration, $60 \%$ at finishing and packing, and $17 \%$ of respondents in the customer service position. These facts occur because of majority of small industrial work is still done manually so for production jobs that require high-risk labor force, still rely on male employees. It turns out the women who are involved in small-scale industries in the district of manufacturing commodities Sumedang feel that there are gender equality or they are not feel there are gender inequality at the workplace. But there is still inequality in the family even though they not feel that it is an inequality. They do not get deserved recognition of his family although they have been working to help their husbands in order to improve economy of family. These results are represent that when women perform multiple roles in the domestic and public areas, it's considered reasonable because she should help the economy of the family, while the men's double role to help resolve household work has not been fully accepted. 


\section{Reference}

Abrar, N. \& Ghouri, A. M. (2010). The Women Violence in Pakistan: Evidence from Rural and Urban Areas. European Journal of Social Sciences, 16(2).

Ambaretnani, N. P. (1994). Kedudukan dan Peranan Wanita Dalam Pembangunan Jangka Panjang II. Makalah diskusi panel, PWSW IKIP Bandung, 26 Januari 1994

Babur, Z. U. (2007). Violence against Women in Pakistan: Current realities and strategies for change', Retrieved April 10, 2010, from http://www.epu.ac.at/epu/research/Babur.pdf

Berger, P. L. \& Luckmann, T. (1966). The Social Construction, of Reality. Garden City, NJ: Doubleday

Bolzendahl, C. I. \& Myers, D. J. (2004). Feminist attitudes and support for gender equality: Opinion change in women and men, 1974-1998. Social Forces, 83, 759-790

Biro Pusat Statistik (BPS). (2003). Statistik Industri Kecil dan Kerajinan Rumah Tangga

BPS. (2005). Profil of Gender Statistik.

Chattopadhyay, M., Chakraborty, S. \& Anker, R. (2013). Sex segregation in India's formal manufacturing sector. International Labor Review, 152(1), 43-58.

Collins, P. H. (1990). Black feminist thought: Knowledge, consciousness, and the politics of empowerment, New York: Routledge.

Ekpe, I. (2011). Women Entrepreneurs and Economic Development in Nigeria: Characteristics for Success. International Journal of Business and Social Science, 2(1).

Faridi, M. Z., Imran, S. C. \& Mumtaz, A. (2009). The Socio Economic and Demographic Determinants of Women Work Participation in Pakistan: Evidence from Bahawalpur District. South Asian Studies A Research Journal of South Asian Studi, 24(2).

Judd, C. M. \& Park, B. (1993). Definition and assessment of accuracy in social stereotypes. Psychological Review, 100(1), 109-128.

Khalique, M., Isa, A. H. M., Shaari, J. A. N. \& Baba, H. (2011). Role of Women in SMEs and Facing Challenges in Pakistan. Interdisciplinary Journal of Contemporary Research in Business, 3(3), 1292-1295.

Naomi, P. \& Alex, A. (2004). Profil Industri Kecil Sebagai Acuan Penerapan Pola Pembinaan dan Pemberian Bantuan (studi Kasusu Pada Industri Kecil Manufaktur Unggulan di Kabupaten Sumedang), Laporan Penelitian.

Ram, N., Khoso, I., Raza, S. A., Shafiq, K. \& Shaikh, F. M. (2011). Sustainable Rural Development though Women Participation in SMEs Business Growth in Sindh. Journal of Sustainable Development, 4(1).

Robbins, P. S. (2001). Organizational Behaviour, New Jersey: Prentice-Hall,Inc.

Shaikh, F. M., Shafiq, K. \& Shah, A. A. (2011). Impact of Small and Medium Enterprises SMEs on Rural Development in Sindh. Modern Applied Science, 5(3).

Simanjuntak, S. Y. \& Putra, B. (1995). Produktivitas dan tenaga kerja Indonesia, Jakarta: LSIUP.

Suksesi, K. (1991). Status Dan Peran Perempuan : Apa Arti Dan Implikasi Bagi Studi Perempuan. Warta Studi Perempuan. Media Komunikasi dan Informasi Tentang Studi Perempuan, 2(1).

Villarreal, A. \& Wei-hsin, Y. (2007). Economic Globalization and Women's Employment: The Case of Manufacturing in Mexico. American Sociological Review, 72(3), 365-389. 